\title{
Magyarországi folyók mértékadó kisvízi készletének elemzése a tervezett öntözési fejlesztések szempontjából
}

\section{Analysing the Water Resources of Hungarian Watercourses in Terms of the Planned Irrigation Developments}

A folyamatosan változó hidrológiai viszonyok bizonyos időközönként indokolják felszíni vízmérlegek készitését hazánkban. A rendelkezésre álló vízkészletek kiszámítására több módszert is alkalmazhatunk, azonban a hatályos jogszabályok szerint az augusztusi 80\%-os tartósságú vízhozam a mértékadó. A cikkben a szerző tíz vízfolyás különbözö eljárással kiszámolt vízkészletét hasonlítja össze, majd vízmérlegeket készít a jövőbeli öntözési igények megbecslésével. Az eredmények elemzése után pedig javaslatokat tesz további eljárások és elemzések elvégzésére.

Kulcsszavak: hidrológia, vízkészlet, vízmérleg, vízjog, öntözés

The constantly changing hydrological circumstances require making surface water balances from time to time in our country. Multiple methods can be used to calculate available water resources but according to water laws currently in force, the standard is the August $80 \%$ discharge duration. In the article, the author compares water resources of ten watercourses resulting from different methods, then creates water balances by estimating future water needs. After analysing the results, the author suggests performing new methods and analyses in the future.

Keywords: hydrology, water resources, water balance, water law, irrigation 


\section{Bevezetés}

A jelenleg hatályos magyar felszíni vízkészlet-gazdálkodással kapcsolatos jogszabály alapján a vízfolyásainkon rendelkezésre álló szabad vízkészleteket statisztikai feldolgozással, az augusztusi $80 \%$-os tartósságú középvízhozamok figyelembevételével kell meghatározni. ${ }^{2}$ Ez a módszer az 1970-es évek óta nem változott hazánkban, ${ }^{3}$ azonban az éghajlatváltozás és az átalakuló vízhasználati igények indokolják ennek felülvizsgálatát.

A vízigények változásának fontos gerjesztő oka lehet Magyarországon a Kormány öntözésfejlesztési célkitűzése. 2017-ben kormányhatározat született, amelyben megfogalmazták, hogy az érintett ágazatoknak Öntözésfejlesztési Stratégiát kell előkészíteniük. Általános célkitűzés, hogy az öntözhető területek nagyságát a jelenlegi 100 ezer hektárról 300 ezer hektárra kell növelni az országban különböző infrastrukturális és vízkészlet-gazdálkodási fejlesztések végrehajtásával. ${ }^{5} \mathrm{Az}$ elmúlt években tapasztalt kora tavaszi aszályos időszakok miatt kitolták továbbá az öntözési időszakot, amely a korábbi, április 15-től szeptember 31-ig tartó időszak helyett március 1-jétől október 31-ig tart. ${ }^{6}$

Fentieket figyelembe véve, célom volt elemezni azt, hogy a jelenleg alkalmazott módszertan szerint kielégíthetőek lennének-e a jövőben megnövekedő öntözési vízigények különböző méretű hazai vízfolyásaink rendelkezésre álló vízkészletéből, továbbá elméleti példák alapján vizsgáltam, hogy milyen más módokon lehetne számítani rendelkezésre álló vízkészleteket.

\section{Magyarország rövid vízrajzi jellemzése}

Magyarország a Duna-vízgyűjtő közepén, jellemzően mély fekvésű területen helyezkedik el a Kárpát-medencében, így a környékbeli hegyekben eredő vízfolyások itt érik el a csekély esésű sík területeket. A Kárpátokból érkező folyók igen szélsőséges vízjárásúak, az árvizeket gyakran váltják kisvizes, aszályos időszakok. A vízhasználataink és vízkészlet-gazdálkodásunk jellegéből adódóan évente valamivel több víz hagyja el az országot, mint amennyi a határokon túlról érkezik. ${ }^{7}$

Az országban rendelkezésre álló vízkészleteket és azok hozzáférhetőségét korábban jellemzően nagyobb vízgazdálkodási egységenként elemezték, ennek 1984-es ábrázolását mutatja be az 1. ábra, a 2. ábrán pedig az ország vízfolyásain rendelkezésre álló augusztusi mértékadó készletek ábrázolása figyelhető meg 1994-ből.

30/2008. (XII. 31.) KvVM rendelet a vizek hasznosítását, védelmét és kártételeinek elhárítását szolgáló tevékenységekre és létesítményekre vonatkozó műszaki szabályokról.

3 Márton Attila: A hazai vízkészlet-gazdálkodási gyakorlat változásainak bemutatása a 20. századtól. Hadmérnök, 14. (2019), 3. 65-74.

1744/2017. (X. 17.) Korm. határozat az Öntözésfejlesztési Stratégia megalkotásáról.

Kolossváry Gábor: Magyarország öntözési stratégiája, az öntözésfejlesztés aktualitásai. Agrofórum, 2019. május 1.

2/1997. (II. 18.) KHVM rendelet a mezőgazdasági vízszolgáltató művek üzemeltetéséről.

Varga György (szerk.): Vizek. In Kocsis Károly (főszerk.): Magyarország nemzeti atlasza: természeti környezet. Budapest, MTA Földrajztudományi Intézet, 2018. 70-81. 


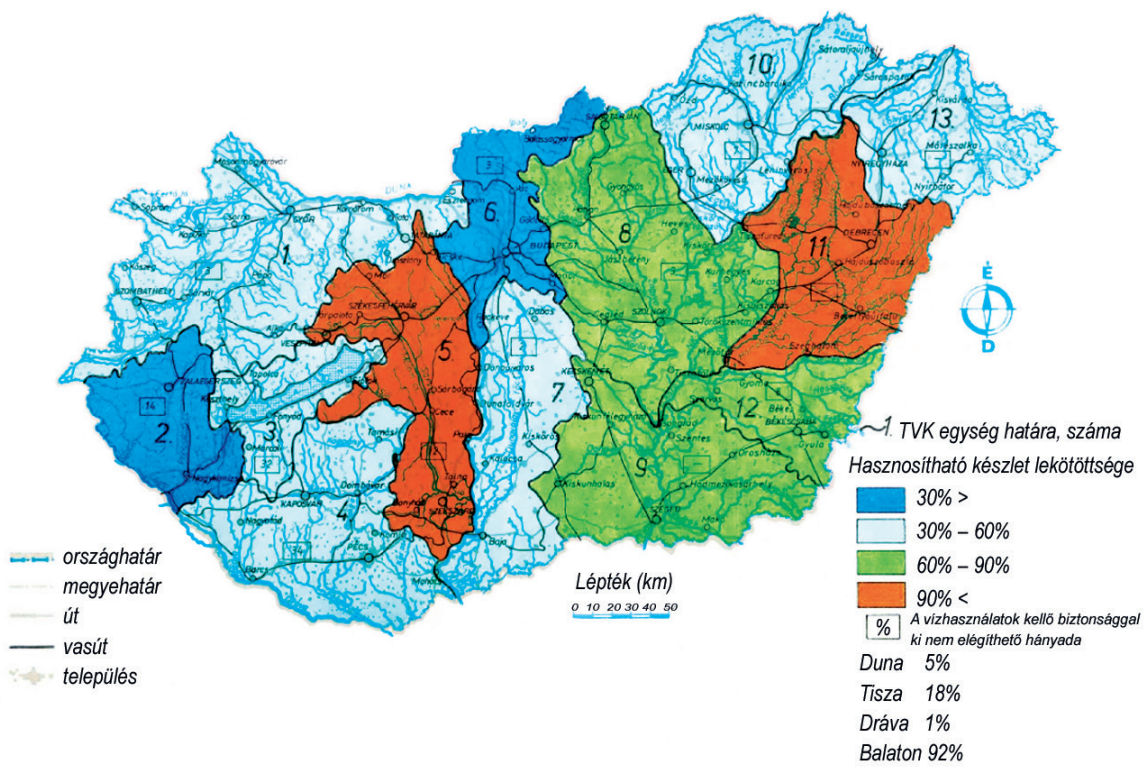

1. ábra. Vízgazdálkodási egységek lekötött készleteinek aránya a rendelkezésre álló készletekhez képest 1984-ben Forrás: Vízgazdálkodási Intézet: Országos Vizgazdálkodási Keretterv. Budapest, Országos Vizügyi Hivatal, 1984, 257.

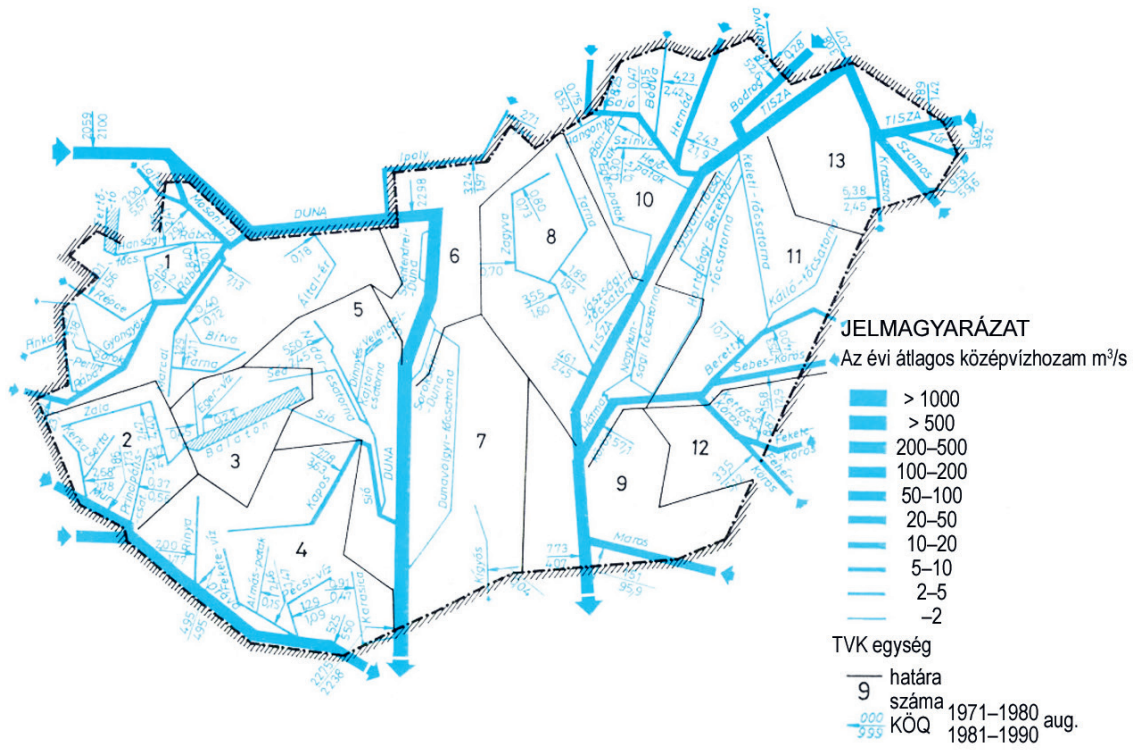

2. ábra. A magyarországi vízfolyások jellemző augusztusi középvízhozamainak ábrázolása 1994-ben Forrás: Liebe Pál (szerk.): Magyarország vizkészleteinek állapotértékelése. Budapest, 1994. 
A fenti ábrákon bemutatott eredmények esetében az látszik, hogy jellemzően a Duna-völgyben állt rendelkezésre nagyobb arányban szabad vízkészlet, amely nem változott az aktuális hidrológiai viszonyok és vízigények figyelembevételével sem. ${ }^{8}$ Napjainkban a vízgyüjtő-gazdálkodási tervekhez készültek ehhez hasonló vízmérlegek, amelyek valamivel kisebb egységben, víztest-vízgyűjtőnként adtak eredményt.

A tervezett számítások elvégzéséhez szükséges vízhozamadatok gyűjtése során 10 vízrajzi állomást választottam ki, majd a Vízügy vízrajzi adatbázisából letöltöttem azok 30 éves (1989-2019) vízhozam-idősorait, amelyek az észlelés sűrüségétől függően akár 200-300 ezer adatot is jelentettek vízfolyásonként. Fontos megemlíteni, hogy ezek az állomások vízállásokat mérnek, amiből vízhozamokat a rendszeres vízhozammérések alapján generált vízállás-vízhozam összefüggésből képeznek a szakemberek.

Automata vízhozammérő berendezések is müködnek az országban, jellemzően a folyók határszelvényei közelében, ${ }^{9}$ viszont ezek fenntartása nehezebb, a berendezések folyamatos kalibrációt igényelnek.

\section{A választott vízmércék környezete és az érintett vízfolyások jellege}

A kiválasztás szempontja az volt, hogy 10 eltérő jellegű vízfolyást elemezhessek, így tágabb képet kapok a módszerek hatékonyságáról. A választott vízmércék a következők voltak:

- Duna, Budapest;

- Tisza, Tiszabecs;

- Hernád, Hidasnémeti;

- Rába, Szentgotthárd;

- Sebes-Körös, Körösszakál;

- Ipoly, Balassagyarmat;

- Kapos, Kurd;

- Zala, Zalaapáti;

- Zagyva, Szentlőrinckáta;

- Galga-patak, Galgamácsa.

8 Országos Vízügyi Főigazgatóság: A Duna-vízgyűjtő magyarországi része. Vízgyüjtő-gazdálkodási Terv. 6-4. melléklet. Budapest, 2015.

9 Országos Vízügyi Főigazgatóság: Vizrajzi adatok (2013. november 15.). 


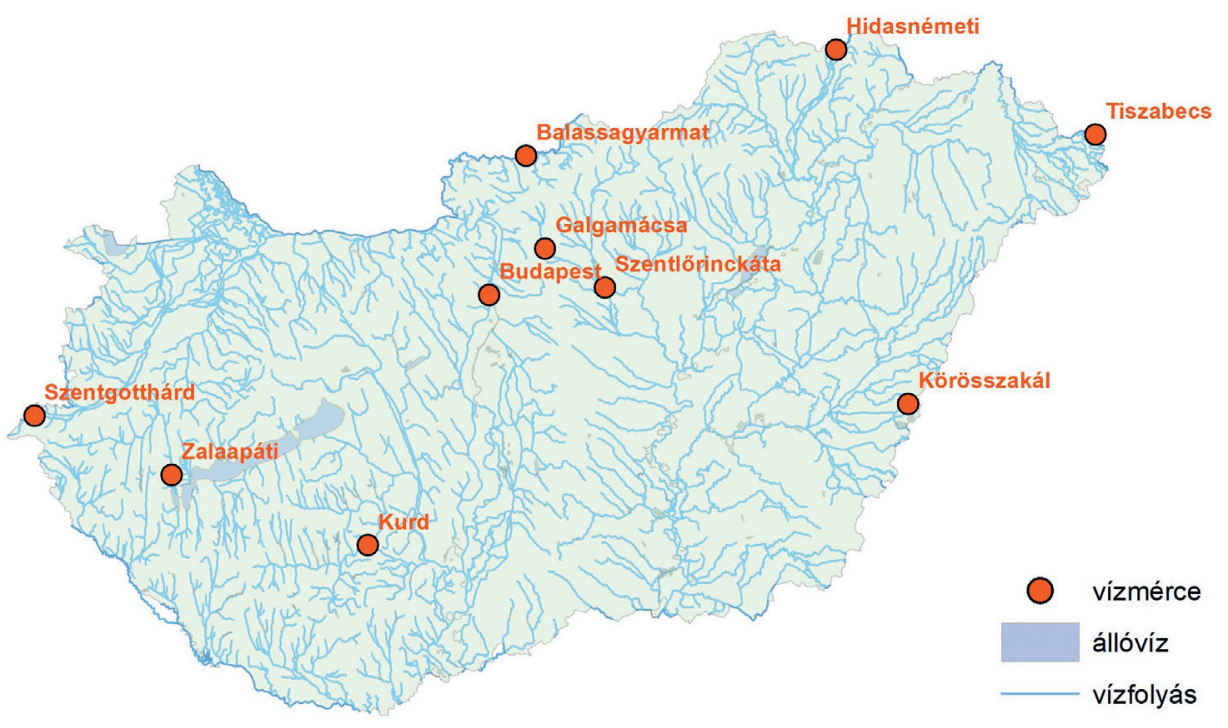

3. ábra. A vizsgált vízmércék elhelyezkedése az országban

Forrás: a szerző szerkesztése

A 3. ábrán látható, hogy a választott vízrajzi állomások lefedik az ország több tájegységét, valamint a vizsgált vízfolyások a nagy folyótól (Duna) a kisebb patakig (Galga) terjednek. A számításaim elvégzéséhez felhasználtam a vízmércékhez tartozó vizgyűijtő területek méreteit is. Az elmúlt 30 év vízrajzi adatai alapján a kijelölt vízfolyások vízjárásának elemzését az 1. táblázat tartalmazza:

1. táblázat. A vizsgált vízfolyások vízrajzi szélsőségei

\begin{tabular}{|c|c|c|c|c|}
\hline állomás & vízfolyás & minimum $\left(\mathrm{m}^{3} / \mathbf{s}\right)$ & maximum $\left(\mathrm{m}^{3} / \mathbf{s}\right)$ & arány \\
\hline Budapest & Duna & 870 & 9200 & 11 \\
\hline Tiszabecs & Tisza & 10.1 & 3700 & 192 \\
\hline Hidasnémeti & Hernád & 5.1 & 480 & 233 \\
\hline Szentgotthárd & Rába & 2.08 & 517 & 646 \\
\hline Körösszakál & Sebes-Körös & 0.8 & 308 & 214 \\
\hline Balassagyarmat & Ipoly & 0.4 & 53.4 & 740 \\
\hline Kurd & Kapos & 0.25 & 91 & 724 \\
\hline Zalaapáti & Zala & 0.123 & 78.9 & 7633 \\
\hline Szentlörinckáta & Zagyva & 0.109 & 22.9 & 770 \\
\hline Galgamácsa & Galga-patak & 0.003 & & 214 \\
\hline
\end{tabular}

Forrás: a szerző szerkesztése 
Látható, hogy minél kisebb a minimum vízhozam, jellemzően annál magasabb a szélsőségek egymáshoz viszonyított aránya, továbbá látható az is, hogy a Dunán érkező vízkészletek mennyisége jelentősen kiemelkedik a hazai vízfolyások közül.

A számítások során kapott adatok összehasonlítását nemcsak a hidrológiai jellemzők, hanem az érintett vízgyűjtők lefolyási sajátosságai és az érintett tájak földrajzi jellemzőinek figyelembevétele mellett lehet megtenni.

A vizsgált vízfolyások közül legkisebb vízgyűjtővel rendelkező Galga völgyhálózata nagyon fiatal, néhány százezer évvel ezelőtt (újpleisztocén) alakult ki. A patak mentén gyakoriak a bádeni andezitkúp-maradványok és az andezitből álló magaslatok, a völgytalpakon erős a lejtők anyagának feltöltődése. A vízgyűjtőn a hóolvadás okozza a nagyobb áradásokat, ilyenkor a Galga gyakran elönti a völgytalpat. A területen a talajvíz az éghajlat és a földtani felépítés miatt kevés, általában a völgytalp alatt 2-3 m-re találjuk meg. A völgy sávjának rétegvízkészlete sem jelentős. ${ }^{10}$

A Zagyva Magyarország legmagasabbra emelkedő hegyvidékének, a Mátra vízgyűjtőjének föbefogadója. A vízgyűjtő két alapvetően különböző jellegű területegységre osztható. A Cserhát és a Mátra hegységek és a hozzájuk csatlakozó dombvidékek az Északi-középhegységhez, míg a Cserhátalja és a Tápió-vidék az Alföldhöz tartozik. ${ }^{11}$ E kettősségből fakadóan a vízgyűjtő igen változatos földtani felépítésű tájakat foglal magában, a vizsgált szentlőrinckátai vízmérce környezetében például hullámos síkság jellegű a táj. Az árvizek a tavaszi hóolvadást követik, míg a kisvizek nyár végén és ősszel gyakoriak. A talajvíz mélysége 2-4 m között mozog a területen. ${ }^{12} \mathrm{~A}$ Zagyva vízjárását jelentősen befolyásolhatja a vízgyüjtő felsőbb szakaszain található völgyzárógátas tározók működése.

A Zala két szerkezeti árokban alakította ki a völgyét. A folyó felső szakasza a forrástól a Zalabér és Türje községeknél lévő kanyarig tart. A vizsgált zalaapáti vízmérce környezete a folyó alsó szakaszához tartozik, amely egy É-D-i irányú szerkezeti árokban kialakult, aszimmetrikus eróziós völgy. Esése jelentős $(1,5 \mathrm{~m} / \mathrm{km})$, de nem egyenletes, mert a mellékpatakok torkolatában nagy mennyiségű hordalék rakódik le. Az árvizek minden évszakban bekövetkezhetnek, de tavasszal a leggyakoribbak. A kisvizek - az ország egyéb kisebb vízfolyásaihoz hasonlóan - jellemzően nyár végén jelennek meg. A talajvíz szintje 2-4 m között mindenhol elérhető a területen. ${ }^{13}$

A Kapos vízgyűjtője nagyrészt dombos felszínű, sík területek a folyó völgyére jellemzők. A terület legmagasabb pontja a Zselicben található, 358 mBf. magasságban. A mellékvízfolyások szinte mindegyikén egy vagy több halastó is található, amely jelentősen befolyásolja a vízfolyásokon az árhullámok levonulását, valamint a hordalékviszonyok alakulását. ${ }^{14} \mathrm{~A}$ kurdi vízmérce a Dél-Külső-Somogy kistáj területén helyezkedik el, amely mintegy 40 km hosszú

10 Dövényi Zoltán: Magyarország kistájainak katasztere. Budapest, MTA Földrajztudományi Kutatóintézet, 2010. 684-685.

11 Közép-Tisza-vidéki Vízügyi Igazgatóság: Jelentős Vízgazdálkodási Kérdések, 2-10 Zagyva vízgyüjtő-gazdálkodási tervezési alegység. Szolnok, 2020.

2 Dövényi (2010): i. m. 195-196.

3 Dövényi (2010): i. m. 421-422.

14 Közép-dunántúli Vízügyi Igazgatóság: Jelentős Vízgazdálkodási Kérdések, 1-12 Kapos vízgyüjtő-gazdálkodási tervezési alegység. Székesfehérvár, 2020. 
és 15 km széles, átlagosan 130-160 m tszf-i magasságú sík terület. A talajvíz a magasabb lösztérszíneken 20-25 m, másutt 6-10 m mélyen, alluviumokon a felszín közelében helyezkedik el. ${ }^{15}$

Az Ipoly folyó a Kárpát-medence szélsőséges vízjárású folyói közé tartozik. A szlovákiai Vepor-hegység délkeleti lejtőjén eredő vízfolyás vízgyűjtőterületének legmagasabb pontja ezer méter fölött van, torkolati szintje pedig alig emelkedik 100 méterrel a tengerszint fölé. Kezdetben igen meredek a folyó völgysíkjának esésgörbéje, a magyarországi szakaszra ellaposodik. ${ }^{16}$ A balassagyarmati vízmérce által érintett kistáj az Ipolytarnóctól Hontig nyúló, szélesebb-keskenyebb völgyszakaszra terjed ki, mintegy 100 km-es hosszúságban. Domborzata teraszos völgymedence képét mutatja, az abszolút magasság 126 és 180 mBf. között változik. A kistáj jelentős vízkincse az Ipoly-menti kavicskitöltésben tározott, parti szürésű talajvíz. ${ }^{17}$ A folyó feszített vízgazdálkodási helyzetben van a vízkivételi igények növekedése és határvízi voltából adódóan. A vízfolyáson több duzzasztómű is található.

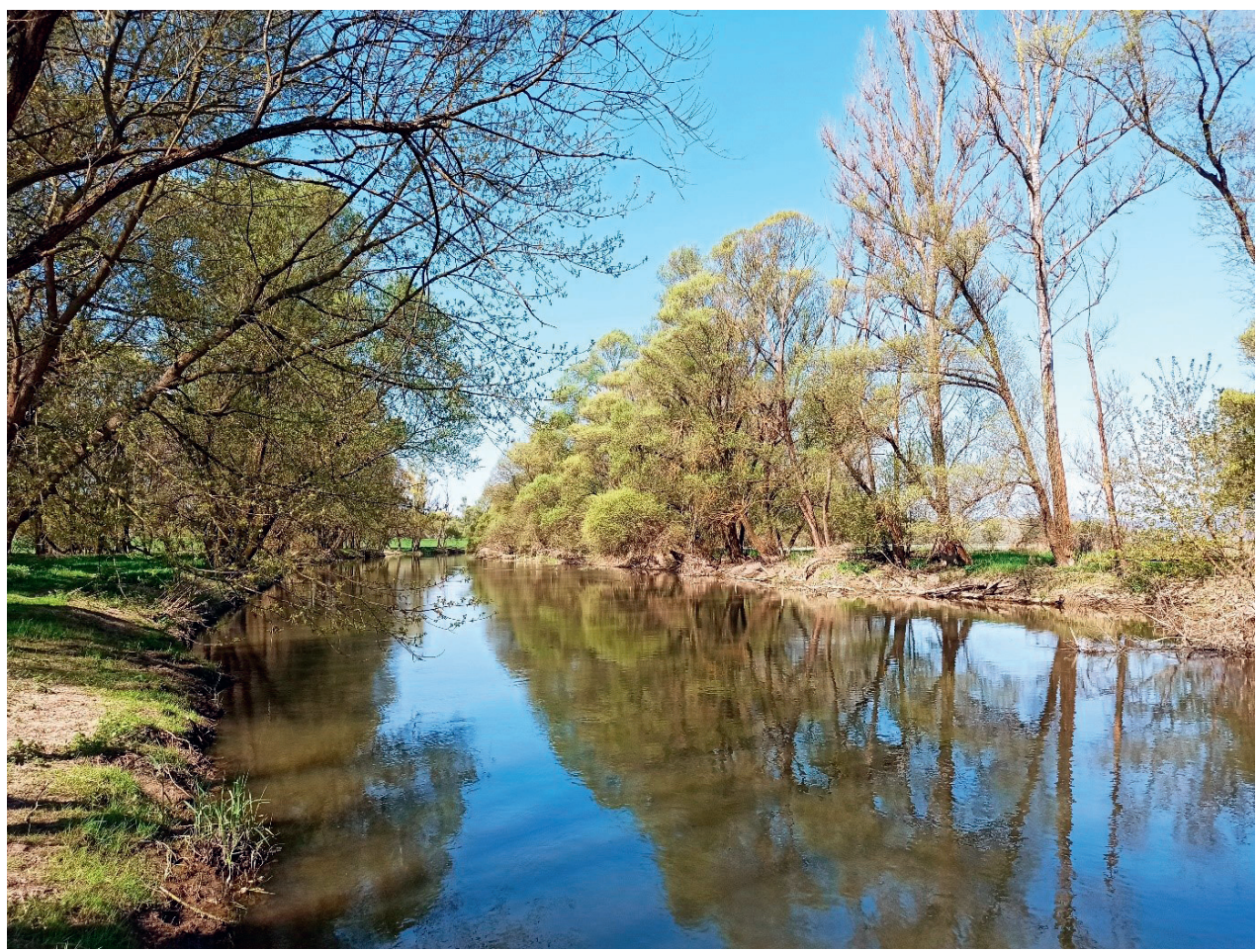

4. ábra. Az Ipoly duzzasztott víztere Balassagyarmat közelében

Forrás: a szerző felvétele (2021. április)

15 Dövényi (2010): i. m. 467-468.

16 Közép-Duna-völgyi Vízügyi Igazgatóság: Jelentös Vízgazdálkodási Kérdések, 1-8 Ipoly vízgyüjtö-gazdálkodási tervezési alegység. Budapest, 2020.

17 Dövényi (2010): i. m. 803-804. 
A Sebes-Körös az Erdélyi-szigethegységben a Réz-hegység és a Király-erdő közötti völgyben ered. A hegyvidéki szakaszán a folyó esése $2,7 \mathrm{~m} / \mathrm{km}$, ezért a folyó vízkészletét a felső és a középső szakaszon elektromosenergia-termelésre használják. A mederben és a mellékpatakok völgyében kiépített 270 millió m³ $^{3}$-nyi térfogatú tározóban (az éves lefolyás 33\%-a) visszatartott víz a turbinákon átengedve a folyó vízjárását kiegyenlíti, így ideális esetben elmaradnak a nyári kisvizek és aszályos időszakban kritikus helyzet jellemzően nem alakul ki. A terület vízhasznosítási igényeinek kielégítése érdekében 1977-re megépítésre került a körösladányi duzzasztómű a vízfolyás $13+550$ fkm szelvényében. ${ }^{18}$ Körösszakál a Sebes-Körös hordalékkúpjának D-i lábánál elhelyezkedő 85,4 és 99,3 m közötti tengerszint feletti magasságú tökéletes síksági kistájhoz tartozik. Az év második felére jellemzőek a kisebb vízhozamok a folyón, a talajvizet 2-4 m mélységben érjük el a területen, mennyisége jelentéktelen. ${ }^{19}$

A Rába az ausztriai Stájer-peremhegység délkeleti lejtőin ered, és Szentgotthárdnál éri el Magyarországot. A Rába-völgy a Nyugat-Dunántúl legnagyobb völgye, árkos süllyedékben keletkezett aszimmetrikus eróziós teraszos jellegű, szembetűnő alakrajzi és szerkezeti vonása a nagy völgyaszimmetria. ${ }^{20}$ Árvizei föleg tavasszal, kisvizei ősszel jelennek meg, a vízjárást módosító beavatkozások egy része ipari célú, más része árvízvédelmi célú beavatkozást jelentett. A vízszintsüllyedés miatt a Rába kis- és középvíztrendjei csökkenő tendenciát mutatnak. Szentgotthárdon egy duzzasztógát létesült a múlt században, ipari vízigény kielégítése céljából, a mütárgy teljes körű rekonstrukciójára 2013-ban sor került. A duzzasztó mellett 2017-ben újabb törpe vízerőművel bővült a Rába folyó vízerő-hasznosítása. ${ }^{21}$

A Hernád folyó Szlovákiában, a Király-hegy északi oldalán ered, és Hidasnémeti térségében Abaújvár mellett éri el Magyarországot. A Hernád-völgy kistáj tektonikus árokban elhelyezkedő folyóvölgy. A felszínt egyenlő arányban jellemzik az ártér, az enyhén tagolt síkság, továbbá az alacsony domblábi hátak és lejtők orográfiai domborzattípusok. A tengerszint feletti magasság 118 és 170 m között változik a kistáj területén. Hidasnémetinél a tavaszi és az őszi árhullámok a jellegzetesek. A folyó dús hordaléka miatt hordalékkúp-építő, feltöltő jellegű; a mederfeltöltés üteme $2 \mathrm{~mm} /$ év. A bővizű folyó energiáját a gibárti és a felsődobszai erőművekkel használják ki. A völgy durva üledékének jelentős parti szűrésű talajvízkészlete van, amely általában 2 m-nél magasabban elérhető. ${ }^{22}$

A Tisza két forrásból ered a Keleti-Kárpátokban, Ukrajnában, majd a Szatmári-sík kistájon Tiszabecsnél éri el Magyarországot. A kistáj 123,8 és 108 m közötti tengerszint feletti magasságú, DK felől ÉNy-nak lejtő tökéletes síkság. A folyón a nagyvizek időpontja általában a kora nyár, az 1998 óta levonult nagy árvizek azonban már tavasszal voltak, kisvizek ősszel és télen jellemzőek. A talajvíz átlag 2-4 m között található, de a medreket kísérő folyóhátak alatt $4 \mathrm{~m}$ alá süllyed. ${ }^{23}$

18 Körös-vidéki Vízügyi Igazgatóság: Jelentös Vizgazdálkodási Kérdések, 2-14 Sebes-Körös vízgyűjtö-gazdálkodási tervezési alegység. Gyula, 2020.

19 Dövényi (2010): i. m. 266-267.

20 Dövényi (2010): i. m. 387-388.

21 Nyugat-dunántúli Vízügyi Igazgatóság: Jelentős Vízgazdálkodási Kérdések, 1-3 Rába vízgyüjtő-gazdálkodási tervezési alegység. Szombathely, 2020

22 Dövényi (2010): i. m. 850-851.

23 Dövényi (2010): i. m. 140-141. 
A Duna menti síkság Vác-Pesti-Duna-völgy kistáján található a budapesti vízmérce. A kistáj túlnyomóan 98 m tengerszint feletti magasságú ártéri síkság, legmagasabb pontja 122 m. Felszíni formáinak döntő többsége a folyóvizek eróziós és akkumulációs tevékenységéhez kapcsolódik. A Dunán a nyár eleji árvíz a megszokott az őszi-téli kisvizekkel szemben. A talajvíz mennyiségét a Duna jelentős mértékben befolyásolja, árvízkor tetemesen emelkedik, kisvízkor csökken. ${ }^{24} \mathrm{~A}$ folyó vízgyűjtőjének mérete, ezáltal mértékadó vízkészletei is jelentősen magasabbak a többi vizsgált vízfolyásénál. A Duna magyarországi szakasza felett számos duzzasztómű befolyásolja az érintett szakaszok hidromorfológiáját.

\section{A számítások elvégzésének menete}

Egyszerüsítésképp nem a napi középvízhozamok tartósságát számoltam ki, hanem az összes mért értéket vettem figyelembe egy adott időszakban. A mért értékeket egyenlő osztályközökre osztottam, megvizsgáltam, hány darab érték tartozik egy-egy osztályba, majd ábrázoltam az adatsor tartósságát az 5 . ábrán látható módon. ${ }^{25}$

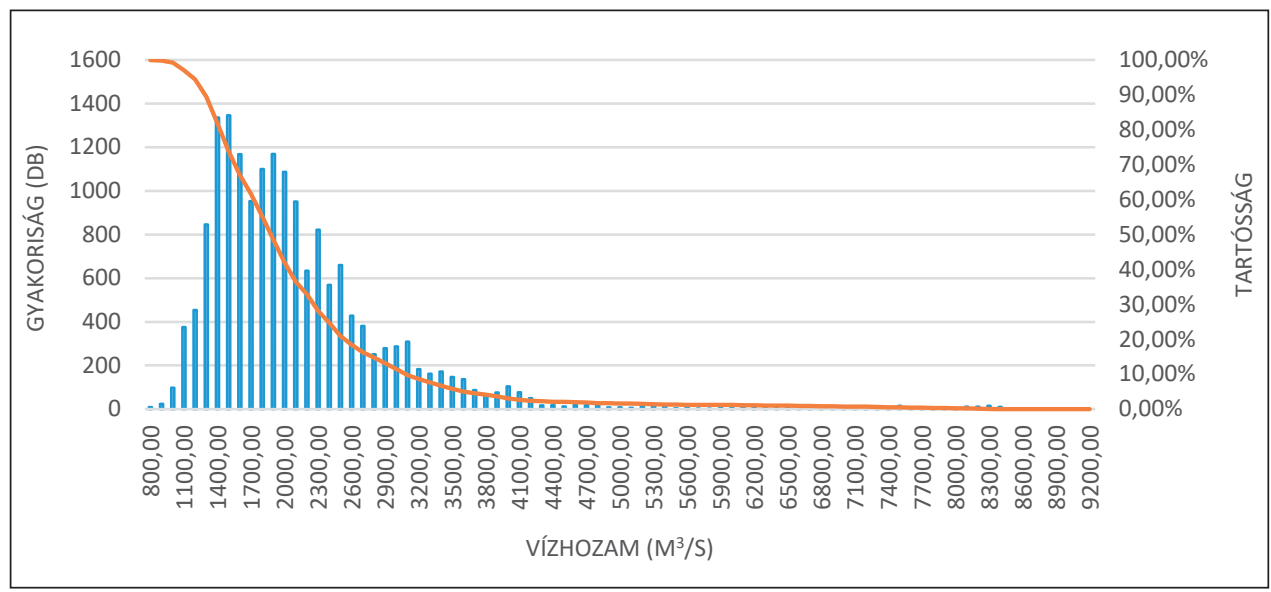

5. ábra. A Duna budapesti vízmércéjén augusztusban mért vízhozam-értékek gyakorisága és tartóssága (1989-2019)

Forrás: a szerző szerkesztése

Ugyanezt az eljárást alkalmaztam az elemzésben vizsgált többi statisztikai érték kiszámításához is. A kapott tartóssági görbékröl leolvashatók voltak a keresett tartósságok. Bár a szakirodalomban az adatok elemzése során jellemzően eloszlásfüggvényeket használnak, a rendelkezésre álló adatok nagy mennyisége miatt külön eloszlásfüggvények alkalmazását nem tartottam szükségesnek a számítások során.

24 Dövényi (2010): i. m. 26-27.

25 Kontur István - Koris Kálmán - Winter János: Hidrológiai számítások. Budapest, Akadémiai Kiadó, 1993. 392-397. 
Ahhoz, hogy a vizsgált mértékadó vízhozamokat össze lehessen hasonlítani, egyszerű vízmérleg készítésére volt szükség. A készlet oldalt a számított vízhozamok adják, az igény oldalt pedig elméletben vizsgáltam Magyarország öntözési viszonyai és az ökológiai igények alapján.

A vízmércékhez tartozó augusztusi $80 \%$-os tartósságú $\left(\mathrm{Q}_{\text {aug80 }}\right)$ értékek felét vettem ökológiai vízigényeknek $\left(\mathrm{Q}_{\text {Öко }}\right)$, a vízgyüjtő-gazdálkodási tervekben alkalmazott magyar gyakorlatot alapul véve. ${ }^{26}$ Ennél a módszernél az ökológiai vízigény függ a víztest típusától is, azonban mivel ez is becslésnek tekinthető, így ezt az 50\%-os értéket használtam.

Az öntözési igényeket a következő logika szerint határoztam meg:

- Napjainkban közel 100 ezer hektár öntözhető terület van Magyarországon, ezt vízgyűjtő területük arányában szétosztottam a vízmércék között.

- 150 liter/év/m² öntözési igénnyel számolva megkaptam az éves igényeket, amit másodperces igényre bontottam le, az öntözési idény hosszával számolva ( $\left.Q_{1}\right)$.

- Kiindulva a fejlesztési stratégiákból, 300 ezer hektár öntözhető területtel is kiszámoltam a fentieket, viszont az éghajlatváltozás hatásai miatt ekkor már magasabb, 160 liter/év/m² fajlagos vízigényt vettem figyelembe $\left(\mathrm{Q}_{1+}\right)$.

A készletoldalon az augusztusi 80\%-os tartósságú vízhozam mellett a következő módszerekkel számoltam még mértékadó vízhozamot:

- Szeptemberi 99\%-os tartósság $\left(\mathrm{Q}_{\text {sz99 }}\right)$ : ismert, a szakma által korábban is alkalmazott mértékadó kisvízi adat.

- Július-október időszak $99 \%$-os tartóssága $\left(\mathrm{Q}_{\text {JAszo99 }}\right)$ : a melegebb és szárazabb hónapok kisvízi értéke.

- Öntözési időszak 99\%-os tartóssága ( $\mathrm{Q}_{\text {ÖNT99 }}$ ): a 2/1997. (II. 18.) KHVM rendeletben meghatározott öntözési időszak kisvízi értéke.

Fentiek számítása a $Q_{\text {aug80 }}$ értéknek megfelelően történt a fejezetben részletezett módszerrel. A számítások elvégzésével az egyszerüsített vízmérleg minden eleme összeállt, így a vizsgált vízfolyásokon megkaptam a mérlegeredményeket. A jelenidejü eredményeket $\left(M_{\mathrm{Q}}\right)$ a különböző módszerek alapján meghatározott, rendelkezésre álló vízkészletekből kivont ökológiai és jelenlegi vízigények adják, a fejlesztések megvalósulása által várható mérlegnél $\left(M_{Q_{+}}\right)$pedig a jövőbeli vízigényeket kellett figyelembe venni, tehát:

$\mathrm{M}_{\mathrm{Q}}=\mathrm{Q}-\mathrm{Q}_{\text {ÖKO }}-\mathrm{Q}_{1}$

$\mathrm{M}_{\mathrm{Q+}}=\mathrm{Q}-\mathrm{Q}_{\mathrm{ÖKO}}-\mathrm{Q}_{1+}$

\section{Az eredmények elemzése}

A számított eredményeket táblázatos formában, illetve diagramokon szemléltettem. A vízigények becslése miatt nem a számszerü eredmények, hanem azok egymáshoz viszonyított

26 Szalay Miklós: A felszíni vizek mennyiségi jellemzése: kisvízi készlet. Budapest, ÖKO Zrt., 2009. 
arányai a fontosabbak. A mértékadó vízkészletek augusztusi 80\%-os tartósságú készlethez viszonyított arányát a 2. táblázat mutatja be, a jelölések magyarázata a 4. fejezetben található.

2. táblázat. A vizsgált vízfolyásokon rendelkezésre álló, különböző statisztikai módszerekkel számított vízkészletek egymáshoz viszonyított arányai

\begin{tabular}{|c|c|c|c|c|c|}
\hline állomás & vizfolyás & $\mathrm{Q}_{\text {aug80 }}$ & $\mathrm{Q}_{\text {sz } 29}$ & $\mathrm{Q}_{\text {JAszog9 }}$ & $\mathrm{Q}_{\text {ont99 }}$ \\
\hline Budapest & Duna & $100 \%$ & $70 \%$ & $69 \%$ & $72 \%$ \\
\hline Tiszabecs & Tisza & $100 \%$ & $53 \%$ & $57 \%$ & $59 \%$ \\
\hline Hidasnémeti & Hernád & $100 \%$ & $63 \%$ & $46 \%$ & $50 \%$ \\
\hline Szentgotthárd & Rába & $100 \%$ & $59 \%$ & $60 \%$ & $65 \%$ \\
\hline Körösszakál & Sebes-Körös & $100 \%$ & $11 \%$ & $20 \%$ & $30 \%$ \\
\hline Balassagyarmat & Ipoly & $100 \%$ & $39 \%$ & $50 \%$ & $54 \%$ \\
\hline Kurd & Kapos & $100 \%$ & $52 \%$ & $55 \%$ & $63 \%$ \\
\hline Zalaapáti & Zala & $100 \%$ & $65 \%$ & $62 \%$ & $81 \%$ \\
\hline Szentlörinckáta & Zagyva & $100 \%$ & $39 \%$ & $39 \%$ & $51 \%$ \\
\hline Galgamácsa & Galga-patak & $100 \%$ & $13 \%$ & $17 \%$ & $27 \%$ \\
\hline
\end{tabular}

Forrás: a szerző szerkesztése

Az 1. táblázatban bemutatott minimum és maximum vízhozamokkal, valamint a szélsőségességgel nincs szoros kapcsolata a kapott értékeknek, ugyanis a számsorok egymáshoz viszonyításakor kapott korrelációs értékek 0,45 ésés -0,6 között alakultak (minél közelebb van a korrelációs együttható a +1-hez vagy-1-hez, annál erösebb a korreláció a tömbök között). Látható, hogy a Duna arányosított eredményei a legmagasabbak, azonban ennek a folyónak a mértékadó vízhozamai jelentősen magasabbak a többi vízfolyásénál. A mértékadó vízkészleteket a 6 . ábra oszlopdiagramjai szemléltetik.

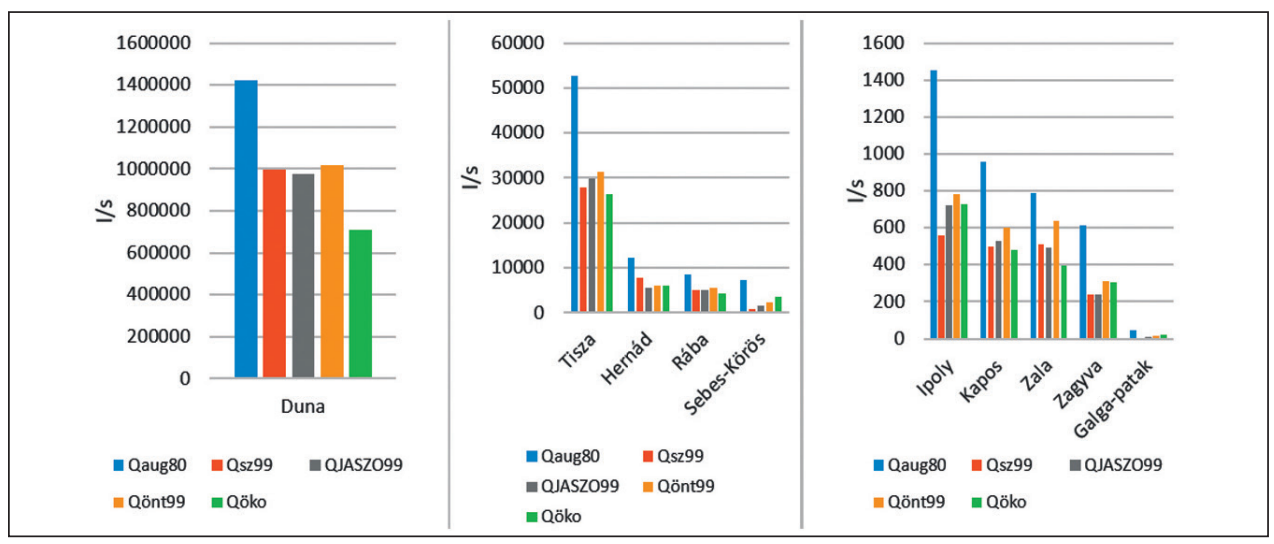

6. ábra. A vizsgált vízfolyásokon rendelkezésre álló, különböző statisztikai módszerekkel számított vízkészletek értékei 
A vizsgált mértékadó vízhozamok közül minden esetben az augusztusi $80 \%$-os tartósságú vízhozam volt a legmagasabb, azonban ez nem meglepő eredmény, mivel a többi esetben 99\%-os tartósságokat vizsgáltam. Általában az öntözési időszakokra vonatkozó készletek adták a legmagasabb értéket, az ábrán is látható, hogy arányaiban annál jobban különbözött két eredmény, minél kisebb egy vízfolyás.

A vízmérleg kiszámítása után kapott jelen idejü eredményeket a 7. ábra szemlélteti. Fontos leszögezni, hogy ezek nem pontos eredmények, a vízigényekre vonatkozó adatokat az összehasonlíthatóság és a jövőbeli változások szemléltetése miatt vettem figyelembe ily módon.

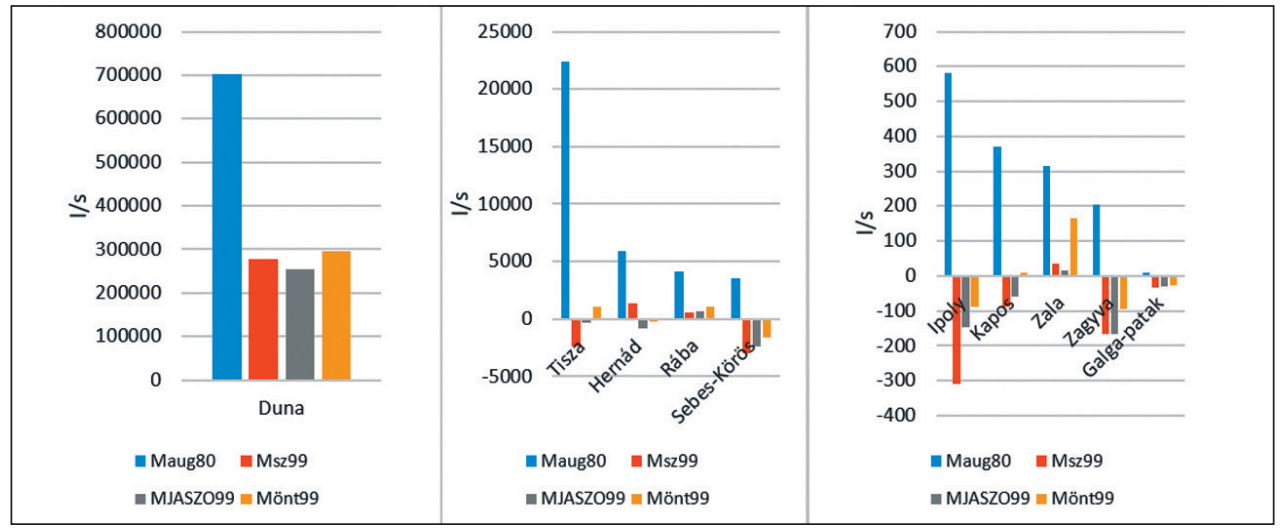

7. ábra. A vizsgált vízfolyások különböző statisztikai módszerekkel számított vízmérleg-eredményei, jelen

Forrás: a szerző szerkesztése

A fentiekben részletezett módszerrel becsült, aktuális vízmérlegek esetében az augusztusi 80\%-os tartósságú értékek minden vízfolyásnál pozitívra adódtak. A különböző 99\%-os tartósságú, tehát szinte biztosan rendelkezésre álló készletek figyelembevételekor már szélsőséges eredményeket kaptam. A Dunát nem figyelembe véve jellemzően a nyugat-magyarországi vízfolyásoknál (Rába, Zala) látszanak ekkor pozitív vízmérlegek, az Ipolyon és a Zagyván viszont, főként a szeptemberi 99\%-os tartósság esetén meglehetősen negatív eredményeket kaptam.

A vízmérleg kiszámítása után kapott, az öntözési fejlesztések elvégzése után becsült eredményeket a 8. ábra szemlélteti. 


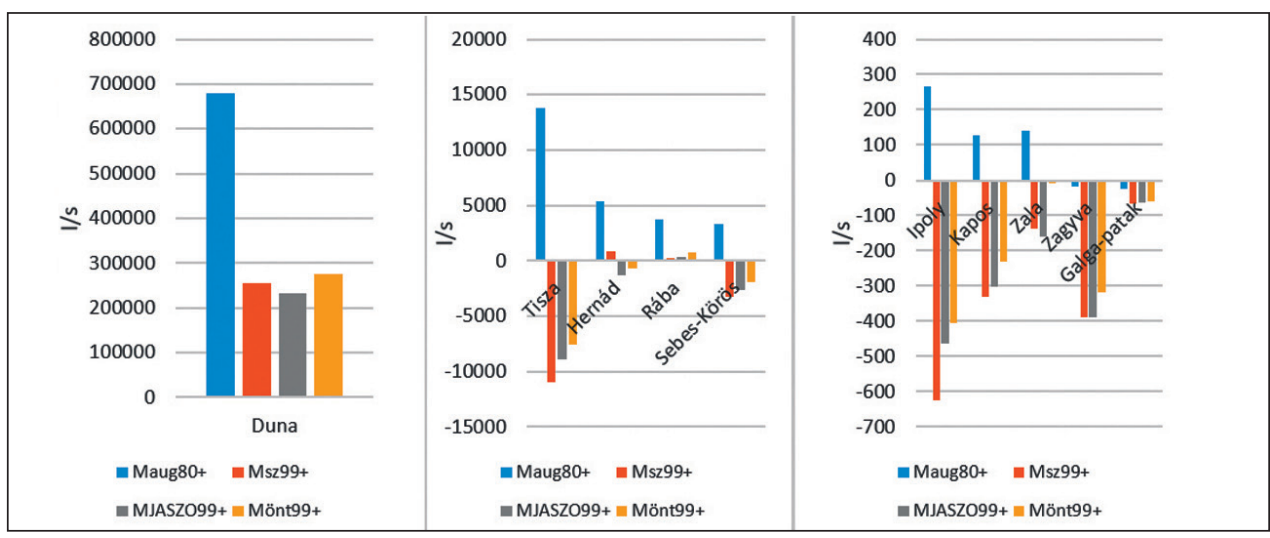

8. ábra. A vizsgált vízfolyások különböző statisztikai módszerekkel számított vízmérleg-eredményei, jövő

Forrás: a szerző szerkesztése

Az öntözési fejlesztések jövőbeli megvalósulása esetén keletkező vízigényekből becsült mérlegek alapján a Dunán rendelkezésre álló vízkészletek arányaiban továbbra sem változnak jelentősen, viszont a többi vízfolyáson - a Rába és a Hernád kivételével - csak negatív értékeket kaptam. Fontos eredmény még, hogy a kisebb vízfolyásokon az augusztusi 80\%-os tartósságú készletekből számolt vízmérlegek is a negatív tartományban mozognak.

Az nem váratlan a mérlegeredmények alapján, hogy minél hosszabb időszakot vizsgálunk, jellemzően annál magasabb a nagyobb biztonsággal rendelkezésre álló készlet, viszont jelentős eltérések vannak az augusztusi $80 \%$-os és a különböző 99\%-os tartósságú készletekkel számított eredmények között.

Ha a konkrét értékeket is figyelembe vesszük, sokszor több száz l/s készlethiányt kapunk, tehát a fejlesztések alapján várható jövőbeli vízigények nem lesznek kielégíthetők felszíni vizekből, a Duna vízkészletének szélesebb körü felhasználása nélkül.

\section{6. Összegzés, következtetések}

Vízmérlegek készítésével az 1950-es évek óta foglalkozik a vízügyi ágazat. Míg vízmérlegekre korábban jellemzően kerettervek készítéséhez volt szükség, ezzel szemben manapság egyre fontosabb cél vízkészleteink pontos ismerete. ${ }^{27} \mathrm{~A}$ cikkben részletezett számítások elvégzése során igyekeztem az utóbbi évek vízrajzi adatai alapján szinte biztosan (99\%-os tartóssággal) rendelkezésre álló felszíni vízkészleteket figyelembe venni különböző típusú vízfolyásokon, hogy reálisabb képet kapjak a felhasználható hazai készletekről.

A számítások fontos eredményének tartom, hogy a kisebb vízfolyásoknál akár tizedakkora készletekkel kell számolni az igények kielégítésének biztosabb becsléséhez, ami azt mutatja,

27 Lásd Márton (2019): i. m. 
hogy amennyiben továbbra is az augusztusi $80 \%$-os tartósságú vízhozamokat kell használnunk, például a vízjogi engedélyezési eljárások során, úgy több korlátozásra lesz szükség a jövőben, ugyanis az augusztusi 80\%-os tartósságú vízhozamok számításával túlbecsülhetők a rendelkezésre álló vízkészletek. Ilyen korlátozások lehetnek például természetes lefolyással rendelkező víztesteken az aktuális vízállásokhoz (vízhozamhoz) kötött vízkivételi korlátozások vagy mesterséges, befolyásolt vízjárású víztesteken az öntözési szolgáltatás szüneteltetése.

A vizsgált adatok közül megfontolandónak tartom - főként a kevésbé szélsőséges vízjárású, nagyobb vízgyüjtővel rendelkező vízfolyások esetében (a vizsgáltak közül: Duna, Hernád, Zala, Rába) - öntözési időszakonként meghatározni a mértékadó készleteket. Ez egyrészt nem jelentene túl nagy szigorítást (általában 60-80\%-a az augusztusi 80\%-os tartósságú értékeknek), másrészt az öntözés biztosabban tervezhető lenne egyes területeken. Az ilyen jellegű vízfolyások földrajzi jellemzői alapján megállapítható, hogy szorosabb kapcsolatban vannak a felszín alatti vizekkel is.

Az eredmények szélsőségei miatt fontos kategorizálni a különböző hazai vízfolyásokat földrajzi és hidrológiai jellemzőik alapján, ugyanis látható, hogy nem lehet ugyanazt a metodikát használni például a szélsőségesebb vízjárású, antropogén hatásoktól erősen függő Sebes-Körös és Zagyva, vagy a jelentősen nagyobb vízgyűjtővel és rendelkezésre álló készlettel rendelkező Duna esetében.

A másik fontos eredmény, hogy az öntözött területek háromszorosára növelésével keletkező vízigény vélhetően nem lesz kielégíthető kizárólag felszíni vizek felhasználásával. Így ha megvalósulnak a fejlesztések, új öntözött területek létesítésekor minden bizonnyal fontos szerepet fognak kapni a vízbeszerzési tervek, ugyanis előfordulhatnak az országban olyan területek, ahol sem felszíni, sem felszín alatti vizek nem fognak adott pillanatban rendelkezésre állni egyéb müszaki megoldások (például tározás) nélkül.

Annak ellenére, hogy az elmúlt évek során voltak erre vonatkozó törekvések, ${ }^{28}$ az eredmények tükrében javaslom olyan további országos tervek elkészítését, amelyekben pontosan le vannak határolva azok a területek, ahol felszíni vagy felszín alatti vízből műszakilag és készlet szempontjából biztosítható öntözési vízellátás.

\section{Felhasznált irodalom}

Dövényi Zoltán: Magyarország kistájainak katasztere. Budapest, MTA Földrajztudományi Kutatóintézet, 2010.

Kolossváry Gábor: Magyarország öntözési stratégiája, az öntözésfejlesztés aktualitásai. Agrofórum, 2019. május 1. Online: https://agroforum.hu/lapszam-cikk/magyarorszag-ontozesi-strategiaja-az-ontozesfejlesztes-aktualitasai/

Kontur István - Koris Kálmán - Winter János: Hidrológiai számítások. Budapest, Akadémiai Kiadó, 1993. Online: https://library.hungaricana.hu/hu/view/VizugyiKonyvek_121/?pg=0\&layout=s

28 Smaragd-GSH Kft.: Öntözésre rendelkezésre álló vízkészletek, valamint az öntözhető területek meghatározása érdekében 2017 márciusában készített vízkészletgazdálkodási térségi terv és stratégiai környezeti vizsgálat eredményeinek felülvizsgálata. Budapest, 2019. 
Körös-vidéki Vízügyi Igazgatóság: Jelentös Vízgazdálkodási Kérdések, 2-14 Sebes-Körös vízgyüjtö-gazdálkodási tervezési alegység. Gyula, 2020. Online: http://vizeink.hu/vizgyujto-gazdalkodasi-terv-2019-2021/jelentos-vizgazdalkodasi-kerdesek-jvk/reszvizgyujto-alegyseg/jvk3-elfogadott/

Közép-Duna-völgyi Vízügyi Igazgatóság: Jelentős Vízgazdálkodási Kérdések, 1-8 Ipoly vízgyüjtő-gazdálkodási tervezési alegység, Budapest, 2020. Online: http://vizeink.hu/vizgyujto-gazdalkodasi-terv-2019-2021/jelentos-vizgazdalkodasi-kerdesek-jvk/reszvizgyujto-alegyseg/jvk3-elfogadott/

Közép-dunántúli Vízügyi Igazgatóság: Jelentös Vízgazdálkodási Kérdések, 1-12 Kapos vízgyüjtö-gazdálkodási tervezési alegység. Székesfehérvár, 2020. Online: http://vizeink.hu/vizgyujto-gazdalkodasi-terv-2019-2021/jelentos-vizgazdalkodasi-kerdesek-jvk/reszvizgyujto-alegyseg/ jvk3-elfogadott/

Közép-Tisza-vidéki Vízügyi Igazgatóság: Jelentős Vízgazdálkodási Kérdések, 2-10 Zagyva vízgyüjtö-gazdálkodási tervezési alegység. Szolnok, 2020. Online: http://vizeink.hu/vizgyujto-gazdalkodasi-terv-2019-2021/jelentos-vizgazdalkodasi-kerdesek-jvk/reszvizgyujto-alegyseg/ jvk3-elfogadott/

Liebe Pál: Magyarország vizzészleteinek állapotértékelése. Budapest, 1994. Online: https://library. hungaricana.hu/hu/view/VizugyiKonyvek_MagyarorszagVizkeszletenekAllapotertekelese/?p$\mathrm{g}=0$ \&layout $=\mathrm{s}$

Márton Attila: A hazai vízkészlet-gazdálkodási gyakorlat változásainak bemutatása a 20. századtól. Hadmérnök, 14. (2019), 3. 65-74. Online: https://doi.org/10.32567/hm.2019.3.6

Nyugat-dunántúli Vízügyi Igazgatóság: Jelentős Vizgazdálkodási Kérdések, 1-3 Rába vízgyüjtő-gazdálkodási tervezési alegység. Szombathely, 2020. Online: http://vizeink.hu/vizgyujto-gazdalkodasi-terv-2019-2021/jelentos-vizgazdalkodasi-kerdesek-jvk/reszvizgyujto-alegyseg/ jvk3-elfogadott/

Országos Vízügyi Főigazgatóság: Vízrajzi adatok (2013. november 15.). Online: www.ovf.hu/hu/ vizrajzi-adatok

Országos Vízügyi Főigazgatóság: A Duna-vízgyüjtő magyarországi része. Vízgyüjtö-gazdálkodási Terv. 6-4. melléklet. Budapest, 2015. Online: www.vizugy.hu/ind ex.php? module=vizstrat\&programelemid=149

Smaragd-GSH Kft.: Öntözésre rendelkezésre álló vízkészletek, valamint az öntözhetö területek meghatározása érdekében 2017 márciusában készitett vízkészletgazdálkodási térségi terv és stratégiai környezeti vizsgálat eredményeinek felülvizsgálata. Budapest, 2019.

Szalay Miklós: A felszíni vizek mennyiségi jellemzése: kisvízi készlet. Budapest, ÖKO Zrt., 2009.

Varga György (szerk.): Vizek. In Kocsis Károly (föszerk.): Magyarország nemzeti atlasza: természeti környezet. Budapest, MTA Földrajztudományi Intézet, 2018. 70-81. Online: www.nemzetiatlasz. hu/MNA/MNA_2_6.pdf

Vízgazdálkodási Intézet: Országos Vízgazdálkodási Keretterv. Budapest, Országos Vízügyi Hivatal, 1984. Online: https://library.hungaricana.hu/hu/view/VizgazdKeretterv_14/?pg=0\&layout=s

\section{Jogi források}

2/1997. (II. 18.) KHVM rendelet a mezőgazdasági vízszolgáltató müvek üzemeltetéséröl. Online: https://net.jogtar.hu/jogszabaly?docid=99700002.khv

30/2008. (XII. 31.) KvVM rendelet a vizek hasznosítását, védelmét és kártételeinek elhárítását szolgáló tevékenységekre és létesítményekre vonatkozó műszaki szabályokról. Online: https://net.jogtar. hu/jogszabaly?docid=a0800030.kvv

1744/2017. (X. 17.) Korm. határozat az Öntözésfejlesztési Stratégia megalkotásáról. Online: https:// net.jogtar.hu/jogszabaly?docid=A17H1744.KOR\&txtreferer=00000001.txt 